\title{
Biological invasions in terrestrial Antarctica: what is the current status and can we respond?
}

\author{
Kevin A. Hughes • Luis R. Pertierra • Marco A. Molina-Montenegro • \\ Peter Convey
}

Received: 5 January 2015/Revised: 13 February 2015/ Accepted: 26 February 2015/ Published online: 10 March 2015

(C) The Author(s) 2015. This article is published with open access at Springerlink.com

\begin{abstract}
Until recently the Antarctic continent and Peninsula have been little impacted by non-native species, compared to other regions of the Earth. However, reports of species introductions are increasing as awareness of biological invasions as a major conservation threat, within the context of increased human activities and climate change scenarios, has grown within the Antarctic community. Given the recent increase in documented reports, here we provide an up-to-date inventory of known terrestrial non-native species introductions, including those subsequently removed since the 1990s, within the Antarctic Treaty area. This builds on earlier syntheses of records published in the mid-2000s, which focused largely on the sub-Antarctic islands, given the dearth of literature available at that time from the continental and maritime Antarctic regions. Reports of non-native species established in the natural environment (i.e. non-synanthropic) are mainly located within the Antarctic Peninsula region and Scotia Arc, with Deception Island, South Shetland Islands, the most impacted area. Non-native plants have generally been removed from sites of introduction, but no established invertebrates have yet been subject to any eradication attempt, despite a recent increase in reports. Legislation within the Protocol on
\end{abstract}

Communicated by Karen E. Hodges.

Electronic supplementary material The online version of this article (doi:10.1007/s10531-015-0896-6) contains supplementary material, which is available to authorized users.

K. A. Hughes $(\bowtie) \cdot$ P. Convey

British Antarctic Survey, Natural Environment Research Council, High Cross, Madingley Road, Cambridge CB30ET, UK

e-mail: kehu@bas.ac.uk

L. R. Pertierra

Área de Biodiversidad y Conservación, Departamento de Biología y Geología, Universidad Rey Juan Carlos, c/ Tulipán, s/n., 28933 Mostoles, Madrid, Spain

M. A. Molina-Montenegro

Centro de Estudios Avanzados en Zonas Áridas (CEAZA), Facultad de Ciencias del Mar, Universidad Católica del Norte, Coquimbo, Chile 
Environmental Protection to the Antarctic Treaty has not kept pace with environmental best practice, potentially presenting difficulties for the practical aspects of non-native species control and eradication. The success of any eradication attempt may be affected by management practices and the biology of the target species under polar conditions. Practical management action is only likely to succeed with greater co-operation and improved communication and engagement by nations and industries operating in the region.

Keywords Antarctic Treaty area - Environmental Protocol · Alien species · Biosecurity · Invasion · Eradication

\section{Introduction}

The vulnerability of Antarctic terrestrial ecosystems to human-induced environmental impacts and changes has been a focus of recent research attention (e.g. Bargagli 2005; Frenot et al. 2005; Kerry and Riddle 2009; Tin et al. 2009; Hughes and Convey 2010, 2012; Cowan et al. 2011; Chown et al. 2012a) and human-assisted establishment of nonnative species, both in the context of those introduced from beyond the Antarctic region and in the movement of Antarctic biota between different eco-regions within the continent, has been identified as one of the most pervasive threats to indigenous ecosystems (Hughes and Convey 2010; Chown et al. 2012b; Terauds et al. 2012).

Antarctica's isolation and recent colonization by humans, compared to the other continents, means it has relatively few known non-native species (Frenot et al. 2005; Hughes and Convey 2010). Globally, intentional non-native species introductions have occurred for economic, scientific and social reasons, frequently with unforeseen consequences for local environments (Mack et al. 2000). However, no terrestrial species introduced to the Antarctic continent intentionally (mainly for scientific research reasons) have been formally identified as invasive (Smith 1996), but intentional introductions to most subAntarctic islands, before the adoption of legislation prohibiting or controlling this activity, have resulted in substantial impacts (see Convey and Lebouvier 2009). Under current legislative systems, unintentional introductions present the greatest threats to sub-Antarctic and Antarctic ecosystems (Frenot et al. 2005), with non-native species potentially being introduced associated with visitors' clothing and personal effects (Whinam et al. 2005; Chown et al. 2012b; Huiskes et al. 2014), cargo (Hughes et al. 2010; Tsujimoto and Imura 2012), building material (Lee and Chown 2009) and fresh foods (Hughes et al. 2011).

It is well recognised that the implementation of effective biosecurity practices is the most cost-effective method of reducing non-native species establishment and subsequent impacts (Chown et al. 2012b) (for examples see the Council of Managers of National Antarctic Programs (COMNAP) and Scientific Committee on Antarctic Research (SCAR) 'Checklists for supply chain managers of National Antarctic Programmes for the reduction in risk of transfer of non-native species', available at: https://www.comnap.aq/SitePages/ checklists.aspx). This is particularly true for Antarctica, where there are relatively few standard access points and routes, and human activities have the potential to be highly regulated by individual national operators and the tourism and fishing industries. However, with increasing numbers of people visiting Antarctica, an increase in the diversity of activities undertaken and the complexity of coordinating management measures between the parties involved, activities that may lead to the introduction of non-native species have 
proven difficult to regulate effectively. Consequently, the introduction and establishment of some new non-native species (as well as the repeated introductions of existing nonnative species in multiple locations) may be almost inevitable (see Fig. 1). Effective management response-including non-native species eradications-is therefore of paramount importance for the protection of Antarctic ecosystems, even accepting that the most effective actions would be to prevent introductions occurring in the first place.
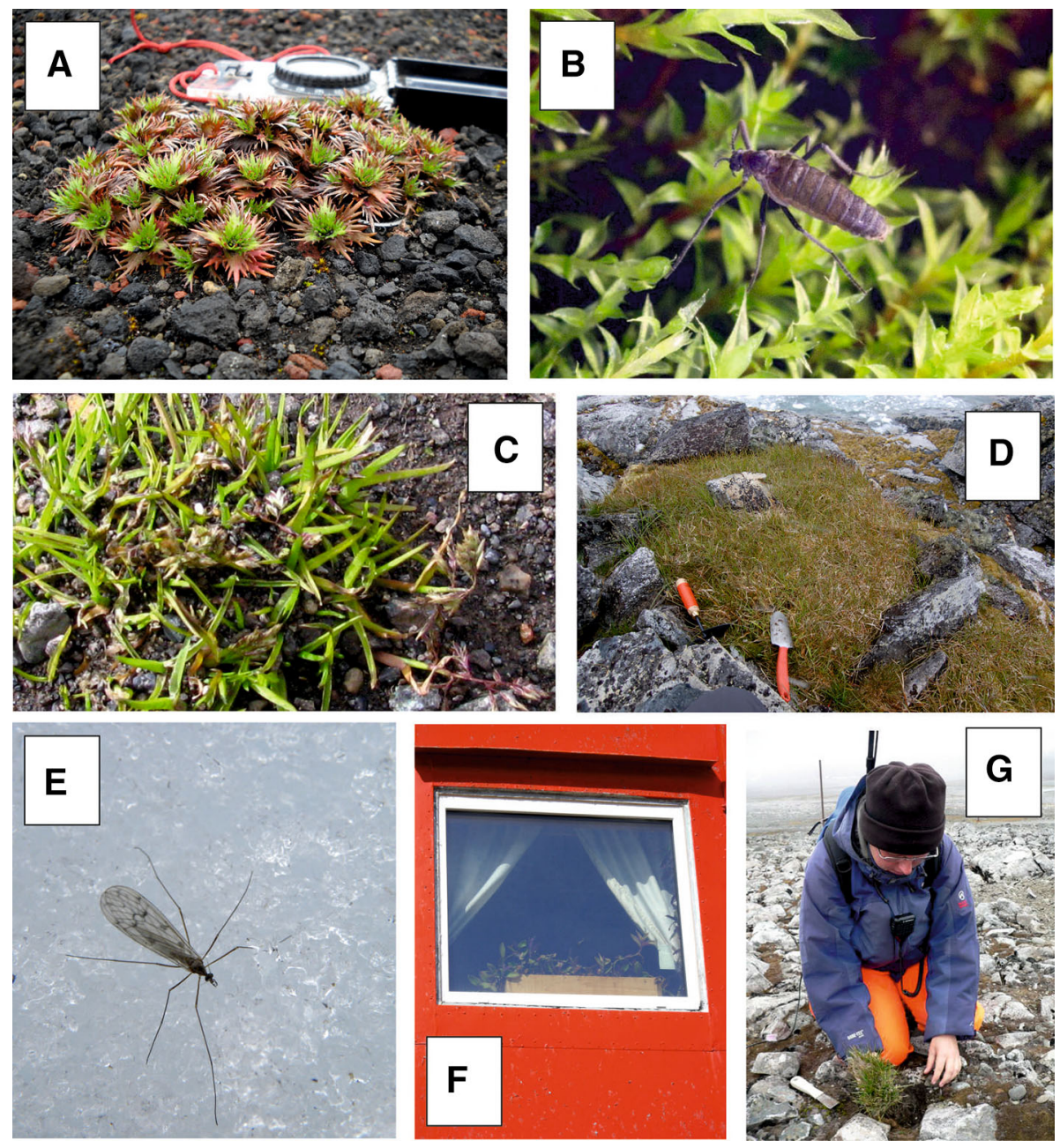

Fig. 1 a Nassauvia magellanica eradicated from Deception Island in January 2010 (Photo: K. A. Hughes). b The flightless chironomid midge Eretmoptera murphyi, introduced to Signy Island, South Orkney Island from South Georgia (Photo: P. Bucktrout). c Poa annua on Deception Island and subsequently eradicated (Photo: M. Molina-Montenegro).]. d Poa pratensis on Cierva Point, Antarctic Peninsula, where it was first introduced during transplantation experiments in 1954/1955 (Photo: L. R. Pertierra). e Trichocera maculipennis found in Artigas Base (King George Island, South Shetland Islands) sewage system in 2006/2007 and in surrounding terrestrial habitats (Photo: O. Volonterio). f Non-native potted plant in the window of Bellingshausen Station in 2010 (King George Island) (Photograph: K. A. Hughes). g Removal of an alien grass species from the vicinity of Great Wall Station, Fildes Peninsula, King George Island in 2006 (Photo: S. Pfeiffer) 
Several previous studies have provided syntheses of the then-existing state of knowledge relating to the presence of non-native species within Antarctica, some including the sub-Antarctic islands within their 'area of interest' (Smith 1996; Frenot et al. 2005, 2008; Convey 2008). Smith's (1996) study focused on records of non-native higher plants, while Frenot et al. (2005) collated information across all terrestrial vertebrate, invertebrate and plant groups, further recognising the paucity of information available relating to lower plant and microbial groups. Over $95 \%$ of the c. 200 established non-native species included in Frenot et al.'s (2005) synthesis were present in the sub-Antarctic, with almost all of the remaining species being recorded from the maritime Antarctic. These reviews, together with related specific studies, have stimulated increasing interest in the risks of biological invasions in the Antarctic, both within the scientific research community and in the governance community of the Antarctic Treaty System, and led to an increase in studies recording the presence and, in some cases, impacts of non-native species within the Antarctic Treaty area (defined as the area south of $60^{\circ} \mathrm{S}$ latitude).

The purpose of this study was therefore to bring the work of Frenot et al. (2005) up to date with regard to the Antarctic Treaty area (excluding the sub-Antarctic Islands), and to examine the number and distribution of macroscopic non-native species introduced or identified since c. 1990 and of any earlier introductions still persisting in the Antarctic terrestrial environment. We also review the current legislation that applies within the Antarctic Treaty area regarding the eradication and control of non-native species, and recommend appropriate management action.

\section{Antarctic terrestrial habitats and biodiversity}

The unique characteristics of habitats and communities with the Antarctic terrestrial environment may make them particularly vulnerable to invasive species impacts. Terrestrial ice- or snow-free habitats in Antarctica comprise only c. $0.34 \%$ of the continental area (Convey et al. 2009), and the majority of this area is devoid of visible or macroscopic biota. Terrestrial biodiversity is low, both in terms of species and functional diversity (Hogg et al. 2006; Convey 2013). Recent biodiversity analyses have identified 15 distinct Antarctic Conservation Biogeographic Regions (ACBRs) within the continent (Terauds et al. 2012). The most developed terrestrial ecosystems are present close to the coast, particularly along the western Antarctic Peninsula and islands along the Scotia Arc, and in oases along the coast of East Antarctica-areas that are also favoured for the siting of research stations, and often coincide with concentrations of wildlife and spectacular scenery that attract tourist activity. However, specialized biological communities are also present even in the most extreme terrestrial habitats within the continent (e.g. Broady and Weinstein 1998; Hodgson et al. 2010). The majority of areas of exposed terrestrial ground are isolated, small and island-like (Bergstrom and Chown 1999; Arnold et al. 2003; Hughes et al. 2006), factors that are important in driving the evolutionary isolation, divergence and high levels of regional endemism that appear to characterise Antarctic biota (Chown and Convey 2007; Convey 2008; Pugh and Convey 2008). Even within the McMurdo Dry Valleys of southern Victoria Land, by far the most extensive area of ice-free ground within the continent, studies of microbial and arthropod communities report signals of isolation and divergence within valleys and catchments (McGaughran et al. 2008, 2010; Chan et al. 2013). Isolation, high levels of endemism and a general lack of inter-species competition within many native terrestrial Antarctic communities may make them particularly vulnerable to the impacts of invasive species (Chown and Convey 2007; Convey 2008). 


\section{The distribution of non-native species within the Antarctic continent}

The known distribution of non-native species within Antarctica is shown in Fig. 2 and the dataset upon which the figure is based is provided in the supplementary data (Table A1). All current introductions are found within the Antarctica Peninsula and Scotia Arc, and all within ACBR 2 'South Orkney Islands' and (by far the most invaded) ACBR 3 'Northwest Antarctic Peninsula'. Although no species appear to be extant, non-native plants have been previously found and removed from continental Antarctica (Japan 1996; Russia 1999). To date, there are no confirmed reports of existing non-native species being transported to further locations within Antarctica, although this possibility presents a significant risk. It should be noted that many Antarctic non-natives are cryptic or non-charismatic, which may make their detection and assured eradication more difficult. Nevertheless, multiple introductions to Arctowski Station (Admiralty Bay, King George Island, South Shetland Islands) of Poa апnиa from both European and South American origins have been reported (Chwedorzewska 2008). Our analyses show introductions to date have been dominated by Collembola and Poaceae, species of both having commonly become established and, in many cases, becoming invasive, on the sub-Antarctic islands (Frenot et al. 2005).

The first report of a non-native plant to become established in Antarctica was of a now absent 'flowering grass' found near houses on Deception Island in January 1936 by the British Graham Land Expedition (Smith 1996); however, the plant known to have persisted longest in Antarctica is Poa pratensis, which was introduced to Cierva Point over 60 years ago with little range expansion before its removal in January 2015 (Pertierra et al. 2013; L. R. Pertierra, pers. obs., 2015). The first non-native invertebrate to be reported was the Collembolan Hypogastrura viatica found on Deception Island in the 1940s (Hack 1949). These findings suggest that the introduction and at least transient establishment of nonnative species is likely to have been occurring for as long as humans have been inhabiting suitable Antarctic locations, and possibly from the early nineteenth century when sealers first visited the northern Antarctic Peninsula and South Shetland Islands. Prior to the implementation of the Protocol on Environmental Protection to the Antarctic Treaty (also known as the Madrid Protocol or Environmental Protocol) in 1998, which prohibited the introduction of non-Antarctic soil, cultivation of non-native plants in imported soil occurred at several Antarctic stations [e.g. Maitri and Novolazarevskaya Stations (Arif and Joshi 1995)] and non-native invertebrate species were reported from within the imported soils (Arif 1995). Furthermore, at some stations considerable quantities of fodder was imported to feed domesticated animals [e.g. c. 30 sheep and 100 fowl were kept at Arturo Prat Station on Greenwich Island, South Shetland Islands (Anonymous 1960)], which was likely to contain viable plant propagules and other non-native species. It would seem appropriate that monitoring for the presence of non-native species in the vicinity of these locations should be a priority (see Smith 1996 for an overview). Contrary to the Environmental Protocol, non-native potted plants are still found in some Antarctic stations in both private quarters and public spaces (for example, potted rose and cycad plants were found to be present at the entrance to Bellingshausen Station, King George Island, South Shetland Islands (P. Convey, pers. obs., 1 Feb 2015) (see also Fig. 1f). At a minimum, Treaty Parties should conform to the legislation contained within the Environmental Protocol and remove non-native species introduced for decorative purposes.

Figure 3 shows the number of discrete locations currently colonised by each non-native species known within Antarctica. The most widely dispersed species are micro-invertebrates, with knowledge of their distributions resulting from recent soil surveys at popular visitor sites (Russell et al. 2013). The Actinedida Speleorchestes sp., Coccotydaolus cf. 


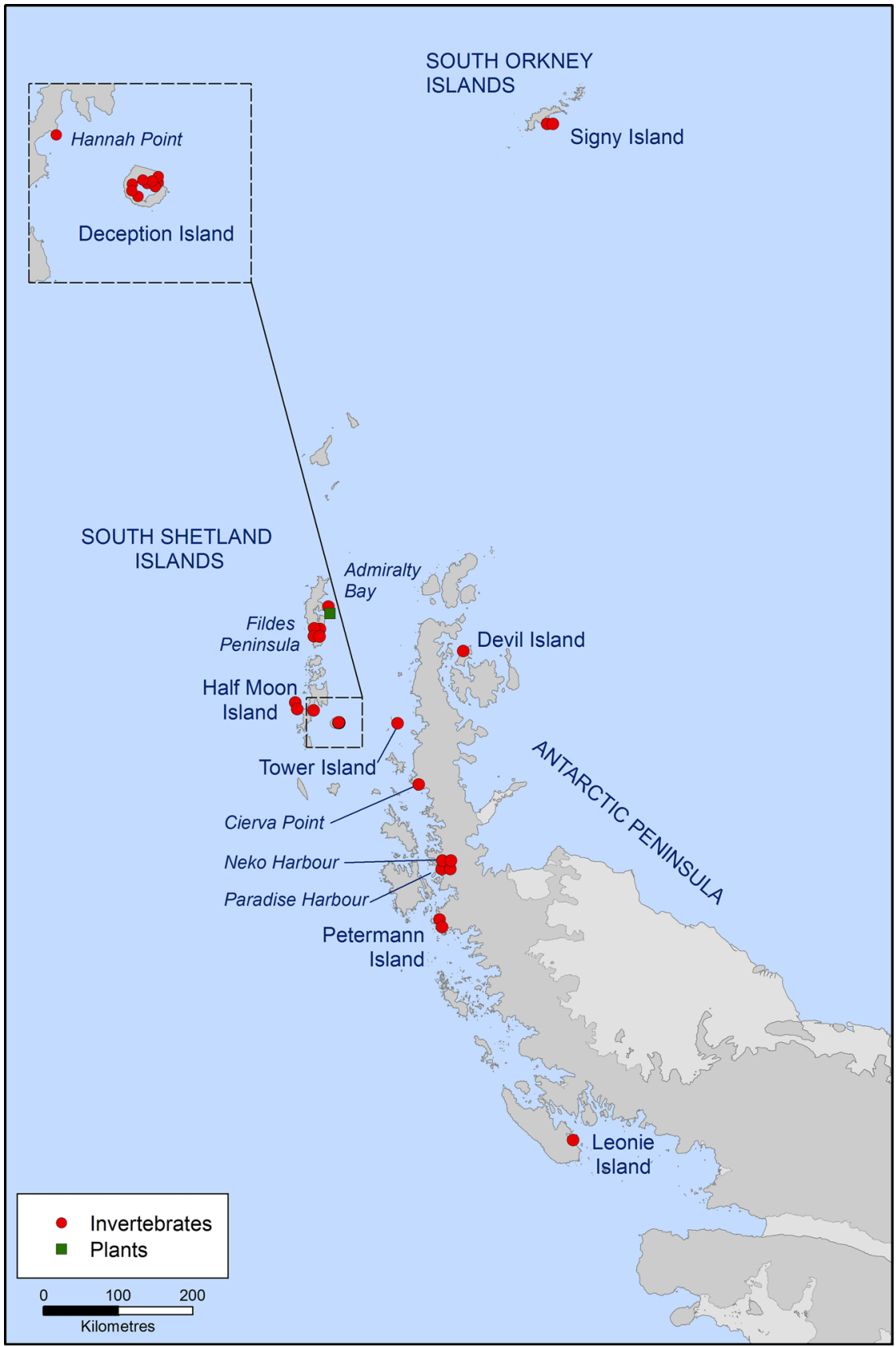

Fig. 2 Map of the Antarctic Peninsula region showing the distribution of known non-native species (Cryptopygus caecus has not been included on this and subsequent maps due to uncertainty over its native/ non-native status (see Russell et al. 2013), while Alicorhagia sp. has not been included as the single report recorded only a single individual and it was unclear whether or not this species had established) 
Fig. 3 The number of locations colonised by each non-native species within Antarctica

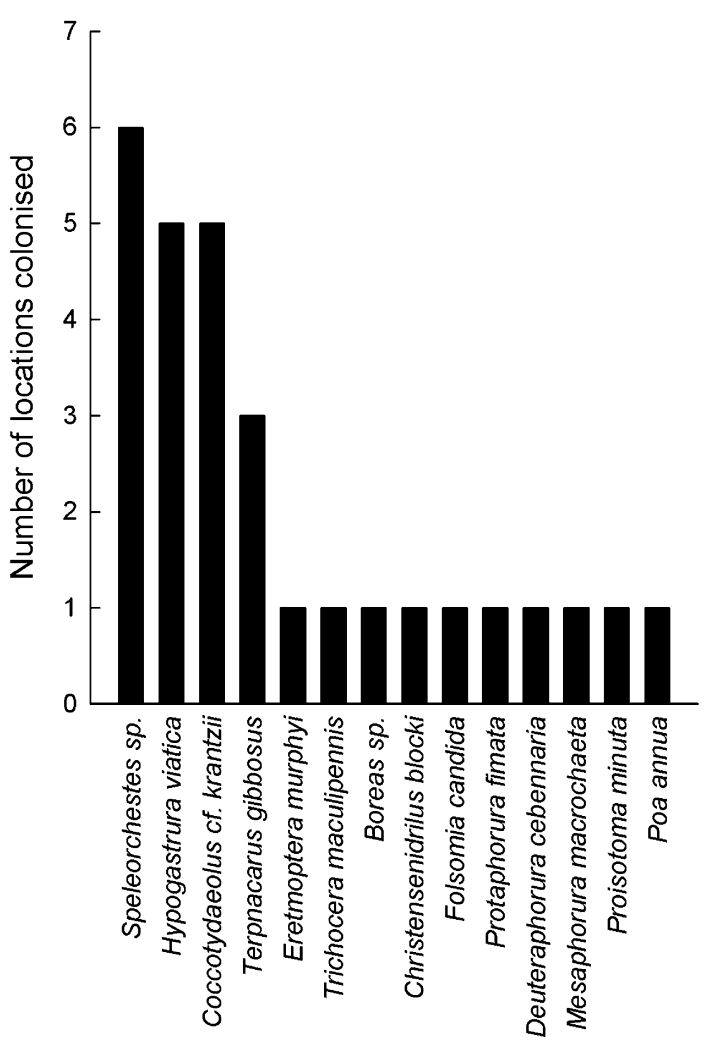

Non-native species

krantzii, Terpnacarus gibbosus and Collembolan Hypogastrura viatica were all found at multiple locations, with Speleorchestes sp. the most widely dispersed across six locations within the northern Antarctic Peninsula and South Shetland Islands area. P. апnиa is now present at only one location (Admiralty Bay, South Shetland Islands), with small numbers of plants being removed from four other locations during the 2009/2010 summer (Deception Island and three sites on the Antarctic Peninsula; see Table 1). Nevertheless, removal is no guarantee of eradication as propagules may remain in the seed bank resulting in the potential reappearance of plants at the site of initial removal. Figure 4 shows the locations currently colonised by at least one non-native species. On the basis of rather limited surveys, Deception Island, with nine non-native species, is the most invaded, followed by Fildes Peninsula and Neko Harbour with four each. All of these locations are subject to high levels of national operator and tourist activity. The majority of other locations containing one or two non-native colonists are close to, or located within, established research stations or popular tourist visitor sites (see Fig. 1 in Molina-Montenegro et al. 2014). These findings are also closely consistent with areas predicted to be at highest risk of non-native species introductions, based on propagule pressure and climate suitability (Chown et al. 2012b).

Figure 5 shows the number of non-native plants (upper panel) and invertebrates (lower panel) discovered within Antarctica over time (pre-1990s, 1990s, 2000s, 2010s). Species 


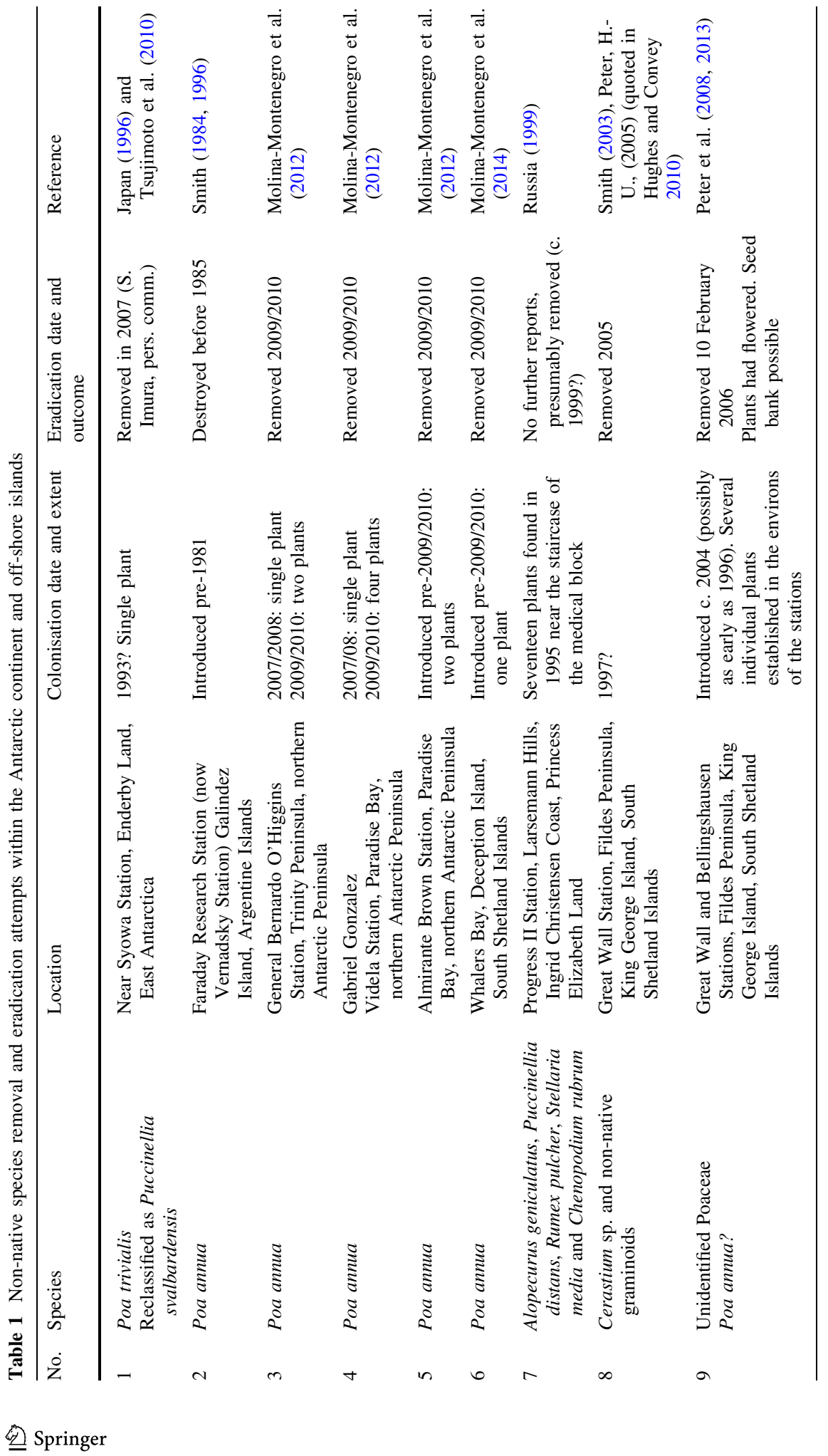




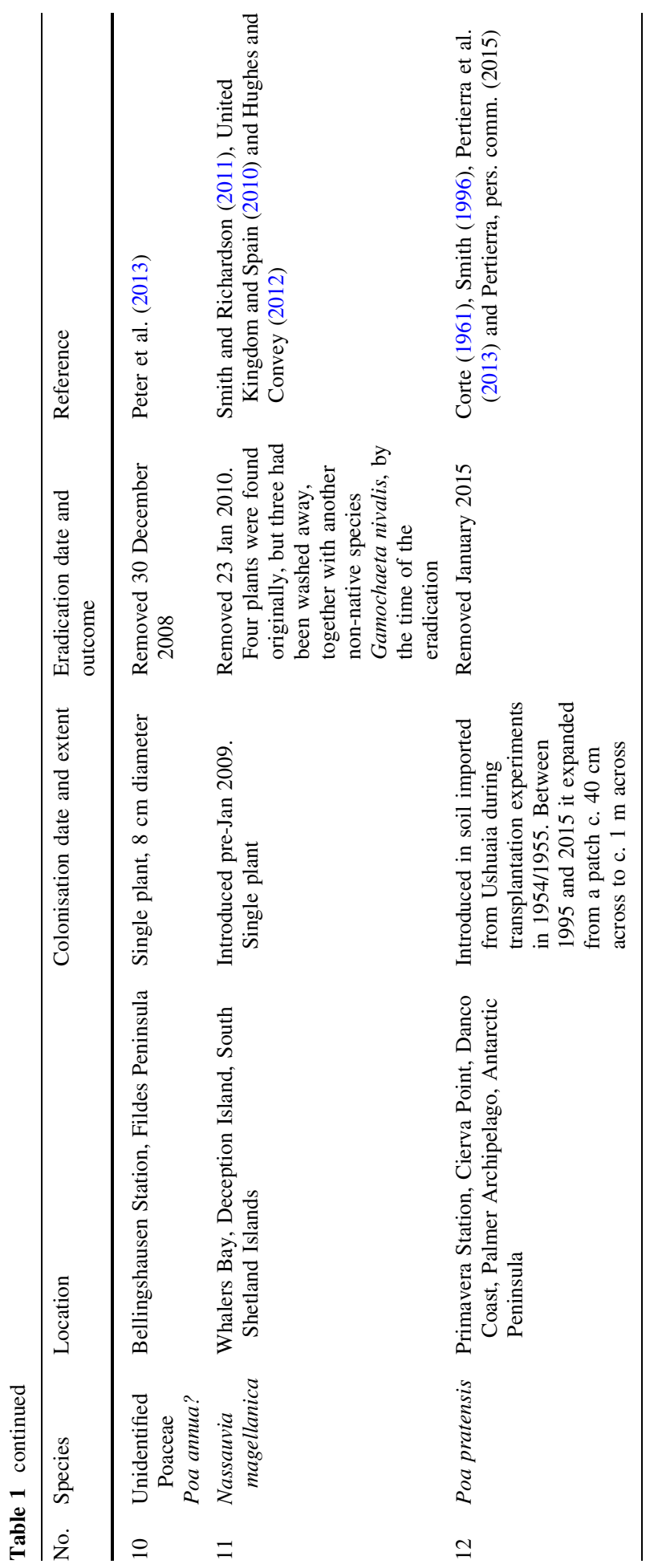


Fig. 4 Number of non-native species present at each invaded location

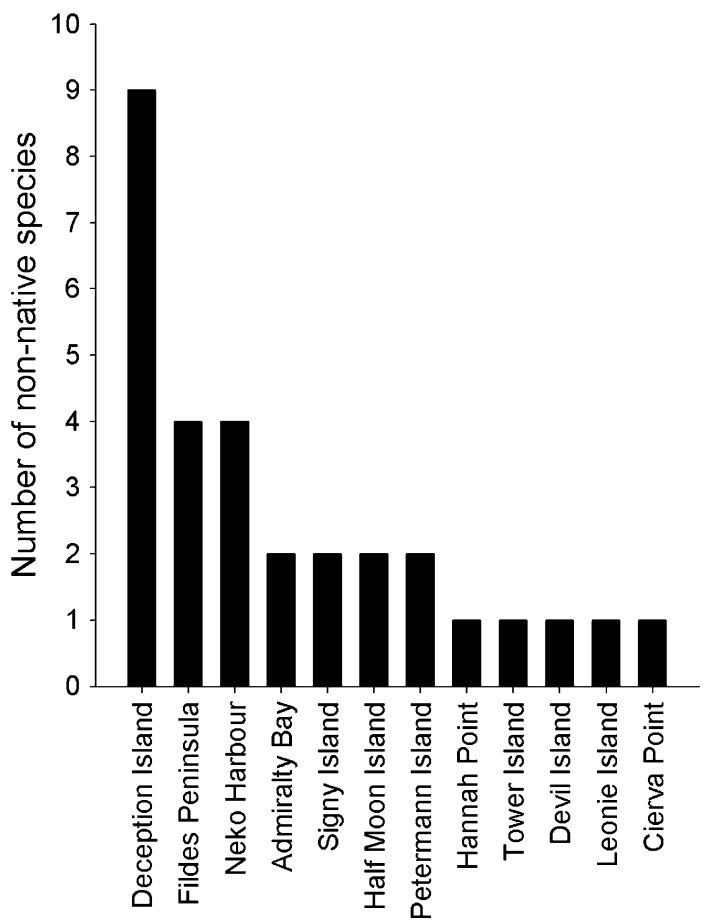

Location

which were introduced deliberately for scientific investigations and were then either removed or did not survive are not included in the analysis (see Smith (1996) for further details). It is clear that removal of single or small numbers of plants at different Antarctic locations has been effectively achieved over recent decades (Argentina et al. 2013), with the notable exception of $P$. аппиа in Admiralty Bay. In contrast, no eradication or control of non-synanthropic invertebrates has been attempted in the region, while recent surveys have resulted in a substantial increase in the number of species and locations known to be invaded by this biological group.

It is not entirely clear which, if any, of the non-native species that have established in Antarctica have become invasive according to the definition contained within the CEP Nonnative Species Manual (2011) i.e. 'are extending their range in the colonised Antarctic region, displacing native species and causing significant harm to biological diversity or ecosystem functioning'. However, the non-native grass, $P$. аnnua has spread into the local terrestrial communities near Arctowski Station and in laboratory experiments has been shown to have negative impacts on photosynthetic performance and biomass of the two native Antarctic vascular plants Colobanthus quitensis and Deschampsia antarctica (Molina-Montenegro et al. 2012). Furthermore, it has been estimated that larvae of the introduced chironomid midge Eretmoptera murphyi, that now occupies an area of over $35,000 \mathrm{~m}^{2}$ on Signy Island, South Orkney Island, may be able to cycle soil nutrients up to nine times faster than the entire native soil invertebrate community and, therefore, could have a major effect on terrestrial habitats across colonised areas on Signy Island (Hughes et al. 2013). 

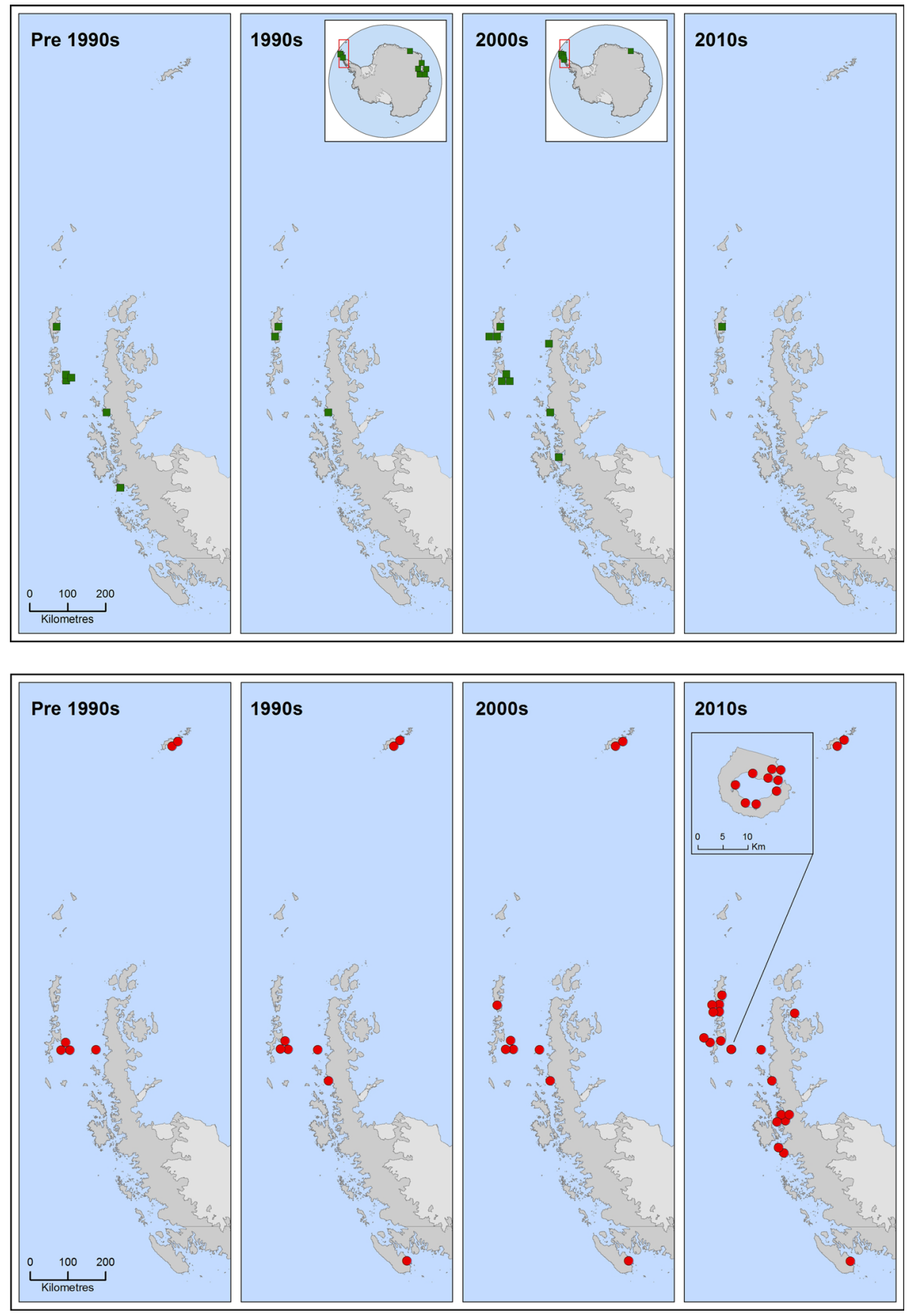

Fig. 5 Location of known non-native plants (upper panel) and invertebrates (lower panel) within Antarctica up until 1990 and during the 1990s, 2000s and 2010s. Plants eradicated or removed are not shown in subsequent figures. No records of non-native invertebrates exist outside the Antarctic Peninsula region and no eradications have been attempted 


\section{Antarctic legislation concerning non-native species and their control and eradication}

General legislation concerning non-native species within the Antarctic Treaty area is reviewed elsewhere (Hughes and Convey 2010, 2014). A brief summary is provided here to give context to the subsequent discussion, with legislation of specific relevance to eradication activities described in more detail.

Legislation relating to non-native species within the Antarctic Treaty area

Legislation relating to non-native species is contained within the Protocol on Environmental Protection to the Antarctic Treaty, predominantly in Annex II Conservation of Fauna and Flora. Article 4 of this Annex prohibits specifically the intentional introduction of non-native plants and animals to land, ice shelves or into water within the Antarctic Treaty area, unless for a defined scientific purpose and in accordance with a permit. Nonnative species can be introduced in accordance with a permit for laboratory studies, but only on the condition that they are destroyed or removed from the Treaty area at the end of the permitted period, and measures are taken to eliminate any potential risks to native plants and animals. The prohibition of non-native species importation does not apply to food items, but no live animal may be imported for human consumption. Furthermore, all imported plant and animal produce (fresh fruit, vegetables, eggs and meat) must be stored under controlled conditions, although there is no general requirement, for instance, for quarantine or inspection facilities, or fumigation of containers used for food transport. Imported animal carcasses must be disposed of by incineration, autoclaving or made sterile before disposal, or be removed from the Antarctic Treaty area. Precautions must be taken to prevent the introduction of non-native microorganisms: diseased meat is not to be imported to the Treaty area and the importation of non-sterile soil originating outside the Treaty area is to be avoided as far as possible. However, the Environmental Protocol makes little reference specifically to the unintentional introduction of non-native species, or the transportation of species (including native species) between different biogeographic regions within the Antarctic Treaty area.

The Protocol does not differentiate between different categories of non-native species (for instance invasive versus persistent; for further discussion of non-native species classifications as have been applied in Antarctica see Frenot et al. (2005) and Greenslade et al. (2012)), rather prohibiting the introduction of all non-native plants, animals and microorganisms, irrespective of likely colonisation status. Consequently, many of the problematic issues faced by policymakers in other regions of the world concerning which nonnative species to allow or tolerate and which to exclude, control or eradicate are not relevant within the Antarctic Treaty area. However, the unusual nature of Antarctica's legislative framework may present disadvantages for conservation, as some legislation applicable elsewhere in the world may not apply in Antarctica (Baker et al. 2005). For example, the Convention on Biological Diversity (CBD) Article 8(h) 'Alien species that threaten ecosystems, habitats or species' does not apply in the Antarctic Treaty area as the CBD itself applies explicitly to sovereign territory. This is despite the fact that many of the Antarctic Treaty signatory nations have themselves signed up to the CBD.

Annex VI to the Environmental Protocol, which has yet to enter into force, concerns liability arising from environmental emergencies. It is unclear if non-native species introductions can be included under the definition of an 'environmental emergency', or if it will be possible to use this legislation to reclaim costs for the control or eradication of a 
non-native species introduced by the actions of another operator (see Hughes and Convey (2014) for further discussion).

\section{Legislation pertinent to non-native species eradication and control}

All activities undertaken by Consultative Parties within the Antarctic Treaty area must conform with the requirements of the Environmental Protocol, as must those of nonConsultative Parties who are signatories to the Protocol. Various issues addressed in the Protocol may have practical implications for the planning and achievement of eradications.

\section{The need for evidence to support eradication or control action}

Annex II, Article 4(4) states that 'Any other plant or animal introduced into the Antarctic Treaty area not native to that area, including any progeny, shall be removed or disposed of, by incineration or by equally effective means, so as to be rendered sterile, unless it is determined that they pose no risk to native flora or fauna'. While this Article is apparently clear that non-native species shall be eradicated, any management action may be directed by two criteria which may be difficult or impossible to prove conclusively, specifically (1) that the species concerned is actually non-native to Antarctica (also noting that the wording does not explicitly recognise the need for removal of species transferred between what are now recognised as biogeographically distinct areas within Antarctica) and (2) that it may pose a risk to native biota (Hughes and Convey 2012). While the rapidity of response to non-native species introductions is a major factor in determining eradication success [and is a key guiding principle in the Committee for Environmental Protection Non-native Species Manual (CEP 2011)], obtaining this information may delay eradication action. A more appropriate policy for Antarctica might be the approach advocated by Simberloff (2003), which is characterized by the principle 'shoot first, ask questions later'. Here, the need for a detailed risk assessment and characterisation of the introduced species followed by investigations into its interactions with other native species (all of which take up valuable time during which the species may be expanding and becoming increasingly difficult to eradicate) becomes of secondary importance. One drawback here, however, is the potential for eradication of species that have colonized Antarctica by natural means, which may impact upon the already very low natural re-colonization rates for the continent (see Hughes and Convey 2012). For the second criterion, one option is that the burden of proof should be placed on managers to show that the non-native species poses "no risk to native flora or fauna', with the meaning of 'risk' defined by scientific experts. Where any doubt exists, eradication should proceed at the earliest opportunity.

\section{The environmental impact assessment process}

All activities planned within the Antarctic Treaty area must undergo some level of environmental impact assessment (EIA) as mandated by Annex I to the Environmental Protocol. Activities assessed as having an impact less than 'minor or transitory' can proceed forthwith. However, in some cases the removal of a non-native species may have an environmental impact that is 'minor or transitory', triggering the need for an Initial Environmental Evaluation (IEE), or impact greater than 'minor or transitory', which would necessitate a Comprehensive Environmental Evaluation (CEE). CEEs must be presented by the proponent Party at an annual meeting of the Committee for Environmental 
Protection, which could cause delays in the commencement of any eradication attempt. Annex I does allow for activities to be undertaken in cases of emergency which would otherwise have required preparation of a CEE. Under such circumstances, notice of the activities 'shall be circulated immediately to all Parties and to the Committee [for Environmental Protection] and a full explanation of the activities carried out shall be provided within 90 days of those activities' [Article 7(2)]. How this would operate in practice is untested as no precedents exist, but at present it seems that individual Parties would decide, on a case by case basis, whether or not the discovery and need to eradicate a non-native species constituted an emergency.

\section{Impacts of non-native species eradication and control activities on non-target native species}

Methodologies used to eradicate or control non-native species may have unavoidable negative effects upon invaded habitats and native species. However, Annex II Article 3(3c) states that 'the diversity of species, as well as the habitats essential to their existence, and the balance of the ecological systems existing within the Antarctic Treaty area be maintained'. While eradication of non-native species may help maintain indigenous species diversity and Antarctic habitats, it is less clear how to assess objectively whether or not the benefits of undertaking the eradication of a non-native species outweigh any potential negative impacts upon indigenous biota. Furthermore, no indication is given as to the spatial scale that should be taken into consideration. For example, eradication of the flightless midge Eretmoptera murphyi and the enchytraeid worm Christensenidrilus blocki on Signy Island, South Orkney Islands, or P. апnua on King George Island may entail destruction of a substantial area of habitat and associated non-target indigenous species (e.g. an area of at least c. $35,000 \mathrm{~m}^{2}$ in the vicinity of the UK research station in the case of E. murphyi, based on a survey carried out in 2007, and recognising that the species appeared to have entered a phase of rapid distribution expansion at that time), and Parties may be reluctant to support such an activity (Hughes and Worland 2010; Olech and Chwedorzewska 2011; Hughes et al. 2013; Olech 1996).

\section{Allocation of permits to undertake eradication or control of non-native species}

Permits issued by an appropriate national authority to take or interfere in a harmful manner with native biota are required and can only be granted to provide specimens for scientific study, to supply specimens for museums and other educational establishments, or to '...provide for the unavoidable consequence of scientific activities......... or of the construction and operation of scientific support facilities'. It is not clear how the destruction of species and habitat as a side-effect of non-native species eradication aligns with this legislation [Annex II, Article 3(2)].

\section{Eradication of non-native species using pesticides}

Practical methods of non-native species eradication may be restricted by Annex III Waste Disposal and Management, as Article 7 states that 'No......pesticides (other than those required for scientific, medical or hygiene purposes) shall be introduced onto land or ice shelves or into water in the Antarctic Treaty area'. Environmental management and conservation purposes are not listed in the Annex, and this issue may therefore require further 
consideration by the CEP and ATCM before use of such chemicals is authorised. Parties' domestic sensitivities regarding the use of these chemicals may further complicate any decision making.

\section{Eradication of non-native species in protected areas}

Further delays in the initiation of any eradication attempt may be encountered if the nonnative species is found within an Antarctic Specially Protected Area (ASPA) or Antarctic Specially Managed Area (ASMA). The accompanying management plans may need to be revised to allow eradication activities to occur, as the disruption of habitat and use of pesticides and herbicides (which are technically a sub-set of pesticides) are generally not permitted. Seventy five percent of all ASPAs, including almost all those that protect terrestrial habitats, prohibit specifically the use of herbicides and pesticides within the Area. The one notable exception to this is contained within the management plan for ASPA 136 Clark Peninsula, Budd Coast, Wilkes Land, East Antarctica, which prohibits herbicides from being taken into the Area '...unless needed to mitigate any non-native species incursions. Such chemicals must only be used as a last resort and controlled by permit conditions.' Within almost all ASPAs the current management plans may limit Parties' choice of methodologies to respond rapidly to a non-native species introduction (Table 2).

\section{Considerations for management of non-native species eradications in Antarctica}

\section{Eradication attempts within the Antarctic Treaty area}

Eradication attempts that have taken place within the Antarctic Treaty area are listed in Table 1. To date, management responses to non-native species introductions to the natural habitats within the Treaty area have either not occurred or have been carried out in an opportunistic or ad hoc manner. Of these, successful eradications have been limited to removal of small numbers of individual vascular plants located near research stations or frequently visited sites. In some cases Parties have been slow to respond to non-native species introductions, despite requests from other organisations. For instance, SCAR recommended that $P$. annua be eradicated from around the Polish Henryk Arctowski Station, Admiralty Bay, King George Island in the early 1990s (Smith 2011). However, although considerable efforts have been made to monitor and study the plants (Olech 1996, 1998, 2003; Chwedorzewska 2008, 2009), no attempt at eradication has been reported (Olech and Chwedorzewska 2011).

Non-native species have also been found living synanthropically within Antarctic buildings, sewage treatment facilities and hydroponic facilities (Hughes and Convey 2010; Volonterio et al. 2013). While successful eradications have occurred within station buildings and hydroponic facilities, no successful eradications of non-native invertebrates have occurred within Antarctic sewage treatment systems (Table 3; Hughes et al. 2005). In the case of the boreal trichocerid fly Trichocera maculipennis, first discovered in the sewage system of the Uruguayan Artigas Base (Volonterio et al. 2013), the history of colonisation, eradication and apparent subsequent recolonisation of the tanks after several years' absence could also be interpreted as being consistent with this pre-adapted cold environment fly having currently undetected source population(s) in the natural environment of King George Island rather than it being restricted to the confines of the station itself. 
Table 2 Measures within Antarctic Specially Protected Area (ASPA) management plans detailing use and storage of herbicides and pesticides within the protected area

\begin{tabular}{|c|c|c|c|}
\hline No. & Management plan measures & ASPA (primary value being protected) & $\begin{array}{l}\text { Percentage } \\
\text { of all } \\
\text { ASPAs \% }\end{array}$ \\
\hline 1 & $\begin{array}{l}\text { Herbicides and pesticides are prohibited } \\
\text { within the Area }\end{array}$ & $\begin{array}{l}54 \text { ASPAs, including all ASPAs primarily } \\
\text { protecting terrestrial habitat }\end{array}$ & 75.0 \\
\hline 2 & $\begin{array}{l}\text { No chemicals to be used in the Area except in } \\
\text { accordance with a permit }\end{array}$ & $\begin{array}{l}\text { ASPA } 120 \text { (birds and mammals), ASPA } 125 \\
\text { (geological values), ASPA } 127 \\
\text { (penguins), ASPA } 166 \text { (historic values) }\end{array}$ & 5.6 \\
\hline 3 & $\begin{array}{l}\text { Chemicals may only be introduced for } \\
\text { permitted scientific or conservation } \\
\text { purposes }\end{array}$ & $\begin{array}{l}\text { ASPAs } 155,157,158,159,162 \text { (all } \\
\text { protecting historic values) }\end{array}$ & 7.0 \\
\hline 4 & $\begin{array}{l}\text { Use of chemicals within the Area is not } \\
\text { prohibited, but storage within the ASPA not } \\
\text { permitted }\end{array}$ & ASPA 174 (geological values) & 1.4 \\
\hline 5 & $\begin{array}{l}\text { 'Chemicals...... which may be brought into } \\
\text { the Area for scientific or management } \\
\text { purposes specified in the Permit, shall not } \\
\text { be released into the environment...' }\end{array}$ & ASPA 175 (geothermal habitat) & 1.4 \\
\hline 6 & $\begin{array}{l}\text { 'No herbicides are to be taken into the Area } \\
\text { unless needed to mitigate any non-native } \\
\text { species incursions. Such chemicals must } \\
\text { only be used as a last resort and controlled } \\
\text { by permit conditions' }\end{array}$ & $\begin{array}{l}\text { ASPA } 136 \text { Clark Peninsula, Budd Coast, } \\
\text { Wilkes Land, East Antarctica }\end{array}$ & 1.4 \\
\hline 7 & No prohibition of chemicals & $\begin{array}{l}\text { ASPA } 122,144,145,146,156,168 . \text { None } \\
\text { protect terrestrial habitat primarily }\end{array}$ & 8.3 \\
\hline
\end{tabular}

Most management plans specifically prohibit use of both herbicides and pesticides, which suggests some confusion over definitions of these terms, as herbicides are a sub-category of pesticides

Table 3 Invertebrates that have colonised station buildings and sewage treatment plants on Antarctic research stations

\begin{tabular}{|c|c|c|c|c|}
\hline Species & Station & $\begin{array}{l}\text { Date } \\
\text { introduced }\end{array}$ & Notes & References \\
\hline $\begin{array}{l}\text { Lycoriella } \\
\text { ingénue }\end{array}$ & $\begin{array}{l}\text { Casey Station, Budd } \\
\text { Coast, Wilkes Land }\end{array}$ & 1998 & $\begin{array}{l}\text { Extensive eradication } \\
\text { attempt in } 2005 \text { proved } \\
\text { unsuccessful }\end{array}$ & $\begin{array}{l}\text { Hughes et al. } \\
(2005) \text { and Smith } \\
(2005)\end{array}$ \\
\hline Lycoriella sp. & $\begin{array}{l}\text { Rothera Research } \\
\text { Station, Marguerite } \\
\text { Bay, Antarctic } \\
\text { Peninsula }\end{array}$ & 2005 & $\begin{array}{l}\text { Successful eradication of } \\
\text { flies from alcohol store in } \\
2005\end{array}$ & $\begin{array}{l}\text { Hughes et al. } \\
\text { (2005) }\end{array}$ \\
\hline $\begin{array}{l}\text { Trichocera } \\
\text { maculipennis }\end{array}$ & $\begin{array}{l}\text { Artigas Station, Fildes } \\
\text { Peninsula, King } \\
\text { George Island, South } \\
\text { Shetland Islands }\end{array}$ & $2006 ?$ & $\begin{array}{l}\text { Early eradication attempt } \\
\text { unsuccessful. Species is } \\
\text { now found in the } \\
\text { surrounding environment }\end{array}$ & $\begin{array}{l}\text { Volonterio et al. } \\
\text { (2013) }\end{array}$ \\
\hline $\begin{array}{l}\text { Unidentified } \\
\text { mosquito }\end{array}$ & $\begin{array}{l}\text { Frei Station, Fildes } \\
\text { Peninsula, King } \\
\text { George Island, South } \\
\text { Shetland Islands }\end{array}$ & $\begin{array}{l}\text { Pre-2009/ } \\
2010 \\
\text { season }\end{array}$ & $\begin{array}{l}\text { Larvae persist in the sewage } \\
\text { treatment plant. No } \\
\text { counter measures are } \\
\text { undertaken }\end{array}$ & $\begin{array}{l}\text { V. Vallejos, pers. } \\
\text { comm., quoted in } \\
\text { Peter et al. (2013, } \\
\text { Sect. 3.1.4) }\end{array}$ \\
\hline
\end{tabular}

Hydroponic facilities, operated by Parties including Australia, New Zealand and the US, have been temporarily closed down and cleaned due to infestations by imported non-native invertebrates (COMNAP 2013) 
Factors affecting the likely success of an eradication within an Antarctic context

Eradication success can depend upon many factors, with each weighted differently depending upon the particular circumstances of each non-native species introduction (Simberloff 2002). It is unlikely that a standard policy for non-native species eradication within the Antarctic Treaty area can be formulated at anything other than the most general level; however, those responsible for controlling non-native species should be wary of delaying extermination (potentially catastrophically) due to lack of complete information. Decisionmaking should benefit from consideration of the following factors:

\section{Economic benefits and use of resources}

In the Antarctic continent, the low number of identified non-native species (and fewer, if any, confirmed invasive species) (Frenot et al. 2005; Hughes and Convey 2012) implies that priorities and resource allocation can still usefully be focused towards implementing effective biosecurity precautions (Rout et al. 2011). Economic drivers for eradications are largely absent as Antarctica has no income generating industries that may be directly impacted by non-native species, such as terrestrial agriculture, freshwater aquaculture or nearshore fish farming (Perrings et al. 2000; Pimentel et al. 2005). Nevertheless, bioprospecting activities, (including those concerning microbial species) may be impacted by non-native species, which could be a driver for improved conservation and/or non-native species control in the future (Hughes et al. 2015).

The Antarctic Treaty Parties have no central reserve to fund environmental initiatives. Consequently Parties, in general, act either independently or in collaboration with a small number of like-minded nations. If eradications are undertaken, it is important that Parties are fully aware of the financial and time (including logistic) commitment necessary from the outset, so that adequate resources are allocate to complete the task. The position in Antarctica contrasts with the sub-Antarctic islands, each of which is governed by a single sovereign nation, and which have experienced a far greater presence and impact of nonnative species (Frenot et al. 2005; Convey and Lebouvier 2009). Here, in recent years, attention has focused on the eradication of various herbivorous and predatory vertebrates, funded either by the national government, or by private or charitable donors (Bloomer and Bester 1991; Frenot et al. 2005; Bergstrom et al. 2009). Some mammalian eradications have led to unintended consequences, such as the destruction of plant species by increased rabbit numbers following the eradication of cats on Macquarie Island (Bergstrom et al. 2009). While high profile, vertebrate eradications represent only part of the challenge as non-native plants and invertebrates represent the majority of known introductions and include a range of invasive species having considerable impacts on ecosystems and native biota (Frenot et al. 2005). Remarkably, within the Antarctic the majority of eradications have removed the vascular plants while no invertebrate eradications have yet been attempted, illustrating the different priorities and capacities for managing different taxa (see Fig. 5).

\section{Lines of authority}

The Antarctic Treaty System operates by consensus, and no mechanism exists by which a Party can be compelled to engage in an activity or cooperate with any eradication plan. Due to ambiguity in the text of the Environmental Protocol, Parties may interpret the legislation in different ways (Joyner 1999), or rank other aspects of their Antarctic 
activities as of higher priority. Within the Antarctic Treaty area, the pace of action may be delayed due to the need for Parties to inform and engage with each other, before undertaking activities not strictly limited to their own logistics and research. Therefore, if a nonnative species is found in an area where operational footprints overlap, eradication attempts may be delayed while consensus between Parties is reached regarding timing, methodology and on-going monitoring, despite the CEP Non-native Species Manual (2011) key guiding principle that any eradication response should be rapid.

An alternative case has been proposed whereby scientists should study the establishment and expansion of non-native species as a research subject itself. This was apparently put forward in response to requests and advice to eradicate $P$. annua from the vicinity of the Polish Arctowski Station in the 1990s (see Smith 2011). Olech (1996) stressed the importance of evaluating properly the effects of man's activities on Antarctic ecosystems which, in the case of $P$. аnnua at Arctowski station, may be one reason that scientific values were prioritised over environmental protection (Smith 2011). However, given the wealth of information already available about biological invasions, their impacts, and their management and the challenges therein available from the rest of the world, the case for any expectation of different principles applying to invasions in Antarctica would seem weak.

\section{Biology of the target species}

A clear understanding of the biology of the non-native species is important when planning an eradication attempt. This is particularly relevant once a species has increased its distribution beyond the initial point of establishment, as eradication and monitoring techniques suitable for small sites may be impractical for larger colonised areas. Important information to guide choice of the most effective eradication methodology can be gleaned from the species' distribution, life cycle characteristics (Thompson et al. 1995; Crawley et al. 1996) and invasiveness in similar environments (e.g. in the sub-Antarctic islands, or in Arctic or high altitude habitats), but with a recognition that these characteristics may be different within an Antarctic context (e.g. see the risk assessments described in Greenslade (2002) and Greenslade and Convey (2012)). Of particular importance is an understanding of which life cycle stages are most likely to aid species dispersal and establishment (e.g. possession of a winged stage, or diapause capacity; production of seeds or vegetative propagules), which are most vulnerable to the eradication methodologies available, the rate of dispersal in other habitats and the physiological limits or thresholds relevant to different life cycle stages. For example, larval size class data and growth rate modelling for the nonnative chironomid midge Eretmoptera murphyi, which was introduced to Signy Island, South Orkney Islands, from South Georgia, has suggested that it persists as larvae in the soil for 2 years on Signy, while this life cycle stage may last only 1 year on the warmer South Georgia (Hughes et al. 2013). The physical, biological and chemical characteristics of colonised ground may affect the rate of spread. For example, disturbed ground may facilitate expansion of ruderal species (Grime 1977), as has been observed in Antarctica with P. annua (Olech 1996; Molina-Montenegro et al. 2014), as could the spatial limits of appropriate microclimatic conditions.

Understanding the phenological strategies and physiological capacities of vascular plants are crucial to designing appropriate methods of eradication. $P$. annua has shown a remarkable flowering capacity even under extreme environmental conditions, therefore any attempted eradications of fast-growing plants (r-strategists) must address the likelihood of an extensive seed bank that may persist long after any physical removal of plants (Pertierra 
et al. 2013; Wódkiewicz et al. 2013). Under these circumstances pesticide use may be effective, combined with on-going monitoring for plant re-growth at the site.

\section{Probability of re-introduction}

Within Antarctica, and between Antarctica and the other southern continents, there are a relatively limited number of logistic routes and connections between locations and, hence, control of species transfer through application of biosecurity measures may be more practicable and effective than in the rest of the world (Chown et al. 2012b; MolinaMontenegro et al. 2012; Hughes et al. 2014). Treaty Parties and tour operators, in large part, are in control of the people and cargo that are transported into Antarctica, and it is largely within their power to control the risk of re-introduction through investment in biosecurity measures. Eradication efforts may be largely wasted if adequate biosecurity precautions that reduce further introductions are not implemented.

\section{Habitat restoration}

An eradication attempt will have failed if indigenous species are driven extinct at the eradication location alongside the introduced species, or are not able to regain earlier population levels. The consequences of an eradication may be hard to predict, but could include negative and unforeseen impacts on local indigenous communities, such as a shift in the dominant native biota at a site (Bergstrom et al. 2009). Given the contemporary relative scarcity of non-native species in Antarctica, to a large extent habitat restoration in Antarctica is not an issue as yet, though it is clearly important in the sub-Antarctic. If Antarctic habitats are damaged by eradication action then, by analogy with the rates of recovery from other impacts (such as ground disturbance or trampling), recovery may require decades at least (Tin et al. 2009).

\section{Practical considerations}

Eradication of many introductions requires trivial commitment of resources [e.g. a person with a spade (see Fig. 1g)], and lessons could also be learnt from previous eradications in the Antarctic and sub-Antarctic (Table 1) (Smith 1984, 2003; Japan 1996; Peter et al. 2008; United Kingdom and Spain 2010; Tsujimoto et al. 2010; Smith and Richardson 2011; Hughes and Convey 2012 (see Table 5 therein); Shaw 2013). Those undertaking an eradication should consider: (1) the most appropriate method (or methods), (2) the implications of there being more than one non-native species at a location and whether it is feasible to eradicate them simultaneously (see Table A1 and Fig. 4), (3) how to prevent inadvertent further distribution of the targeted species in the local area during the eradication work, (4) how best to co-ordinate the proper disposal of any removed organisms and other associated material such as soil or vegetation, and (5) what monitoring programme should be put in place to ensure the eradication has been effective.

\section{Conclusions and recommendations}

The level to which biosecurity measures are implemented by national operators and the tourism industry in the Antarctic has not been rigorously assessed or tested (but see 
COMNAP 2008). However, within Fildes Peninsula, King George Island, which is located in one of the regions at highest risk of non-native species introductions (Chown et al. 2012b, Fig. 4), Peter et al. (2013) reported that 'The various stations of the Fildes Peninsula currently take either no measures or limited measures to prevent the introduction of non-native species... On the contrary, people still commonly keep house plants in a number of stations. To our knowledge, no measures are implemented to monitor nonnative species' (see Fig. 1f). It is not known if this level of engagement in non-native species and biosecurity issues is common throughout Antarctica, but the assessment is a cause for concern, following as it does the matter of non-native species being attributed the highest priority on the Committee for Environmental Protection work plan since first used as a management tool in 2007 [ATCM XXX Final Report (para. 230) http://www.ats.aq/ devAS/ats_meetings_meeting.aspx?lang=e]. Furthermore, recent monitoring activities on the northern Antarctic Peninsula have revealed a higher number and distribution of nonnative species than was previously known (Greenslade et al. 2012; Molina-Montenegro et al. 2012; Russell et al. 2013, 2014), suggesting that biosecurity practices employed to date are not adequate.

Successful management of non-native species will require cooperation between Treaty Parties, national operators, the tourism industry and other stakeholders (Convey et al. 2012). In 2002, Simberloff wrote '...successful eradication may be as much a function of political skill and public education as of technology'. This is likely to be particularly true for Antarctica as consensus is required before any change in legislation can occur or major activity be undertaken. Therefore, the objections of even a single Party could put in jeopardy plans for any sizeable eradication attempt. Furthermore, lack of communication between scientists, policy makers and those putting policy into practice, both within individual nations and across the Antarctic Treaty System, may limit the success of efforts by any one group alone. Initiatives such as the Environments Portal (www.environments.aq), which is supported by several Treaty Parties and SCAR, may go some way in bridging these knowledge gaps. In an attempt to produce a more integrated, comprehensive and dynamic approach to conservation in the region and to inform conservation decisionmaking and policy, including those concerning non-native species, SCAR is developing an Antarctic Conservation Strategy (SCAR et al. 2012).

To reduce the impact of non-native species within the Antarctic Treaty area, almost all areas of management action would benefit from improvement, particularly:

- Better education of all Antarctic visitors.

- Application of consistent and effective biosecurity practices in all Antarctic operations, recognising that 'prevention is better than cure'.

- Monitoring of high activity sites for non-native introductions and suitable reporting, including support for appropriate expertise with which to identify potential introductions.

- The development of contingency plans following the discovery of a non-native species, including the provision of eradication protocols and appropriate equipment.

- Inclusion of information on how to respond to a non-native species introduction within protected area management plans.

- Better use and resourcing of scientific expertise to inform our understanding of nonnative species issues and advise on response action.

Assuming there is the political will to uphold and apply the legislation agreed in the Environmental Protocol, undertaking these activities will make financial sense. The most cost-effective option is to implement measures to prevent introductions in the first instance. 
However, should a non-native species establish, eradication as soon as possible after introduction may still prove relatively inexpensive. Failure to take action, resulting in species expansion, may render eradication practically impossible, leaving control of species spread as the only form of mitigation-a long-term and potentially expensive commitment.

Acknowledgments This review paper is a contribution to the SCAR AntEco (State of the Antarctic Ecosystem) research programme. KH and PC are supported by NERC core funding to the British Antarctic Survey's Polar Science for Planet Earth core programmes 'Environment Office-Long Term Monitoring and Survey' (EO-LTMS) and 'Ecosystems'.

Open Access This article is distributed under the terms of the Creative Commons Attribution License which permits any use, distribution, and reproduction in any medium, provided the original author(s) and the source are credited.

\section{References}

Anonymous (1960) Chilean Antarctic activities. Antarctica: a news bulletin published quarterly by the New Zealand Antarctic Society 2(7):274. http://www.antarctic.org.nz/pastissues.html. Accessed 12 Dec 2014

Argentina, Spain, United Kingdom (2013) The non-native grass Poa pratensis at Cierva Point, Danco Coast, Antarctic Peninsula—on-going investigations and future eradication plans. Information Paper 35. Antarctic Treaty Consultative Meeting XXXVI, Brussels, Belgium, 20-29 May 2013

Arif M (1995) Occurrence of invertebrate fauna in Schirmacher Oasis, Antarctica. Eleventh Indian Expedition to Antarctica, Scientific Report, 1995. Department of Ocean Development, Technical Publication No. 9, pp 301-311

Arif M, Joshi MC (1995) Comparative performance of thirty two crops grown in Antarctic soil, Antarctic moss and peat moss under glass house conditions in Antarctica. Eleventh Indian Expedition to Antarctica, Scientific Report, 1995. Department of Ocean Development, Technical Publication No. 9, pp 267-300

Arnold RJ, Convey P, Hughes KA, Wynn-Williams DD (2003) Seasonal periodicity of physical factors, inorganic nutrients and microalgae in Antarctic fellfields. Polar Biol 26:396-403

Baker R, Cannon R, Bartlett P, Barker I (2005) Novel strategies for assessing and managing the risks posed by invasive alien species to global crop production and biodiversity. Ann Appl Biol 146:177-191

Bargagli R (2005) Antarctic ecosystems: environmental contamination, climate change and human impact. Springer, Berlin

Bergstrom DM, Chown SL (1999) Life at the front: history, ecology and change on Southern Ocean islands. Trends Ecol Evol 14:472-477

Bergstrom DM, Lucieer A, Kiefer K, Wasley J, Belbin L, Pedersen TK, Chown SL (2009) Indirect effects of invasive species removal devastate World Heritage Island. J Appl Ecol 46:73-81

Block W, Christensen B (1985) Terrestrial enchytraeidae from South Georgia and the Maritime Antarctic. Brit Antarct Surv Bull 69:65-70

Block W, Burn AJ, Richard KJ (1984) An insect introduction to the maritime Antarctic. Biol J Linn Soc 23:33-39

Bloomer JP, Bester MN (1991) Effects of hunting on population characteristics of feral cats on Marion Island. S Afr J Wild Res 21:91-102

Broady PA, Weinstein RN (1998) Algae, lichens and fungi in La Gorce Mountains, Antarctica. Antarct Sci 10:376-385

Burn AJ (1982) A cautionary tale-two recent introductions to the maritime Antarctic. Comité National Francais des Recherches Antarctiques 51:521

Chan Y, van Nostrand JD, Zhou J, Pointing SB, Farrell RL (2013) Functional ecology of an Antarctic dry valley. Proc Natl Acad Sci USA 110:8990-8995

Chown SL, Convey P (2007) Spatial and temporal variability across life's hierarchies in the terrestrial Antarctic. Philos Trans R Soc B 362:2307-2331

Chown SL, Lee JE, Hughes KA, Barnes J, Barrett PJ, Bergstrom DM, Convey P, Cowan DA, Crosbie K, Dyer G, Frenot Y, Grant SM, Herr D, Kennicutt MC, Lamers M, Murray A, Possingham HP, Reid K, Riddle MJ, Ryan PG, Sanson L, Shaw JD, Sparrow MD, Summerhayes C, Terauds A, Wall DH (2012a) Challenges to the future conservation of the Antarctic. Science 337:158-159 
Chown SL, Huiskes AHL, Gremmen NJM, Lee JE, Terauds A, Crosbie K, Frenot Y, Hughes KA, Imura S, Kiefer K, Lebouvier M, Raymond B, Tsujimotoi M, Ware C, Van de Vijver B, Bergstrom DM (2012b) Continent-wide risk assessment for the establishment of nonindigenous species in Antarctica. Proc Natl Acad Sci USA 109:4938-4943

Chwedorzewska KJ (2008) Poa апnиа L. in Antarctic-searching for the source of introduction. Polar Biol 31:263-268

Chwedorzewska KJ (2009) Terrestrial Antarctic ecosystems in the changing world—an overview. Pol Polar Res 30:263-273

Chwedorzewska KJ, Bednarek PT (2012) Genetic and epigenetic variation in a cosmopolitan grass Poa апnиа from Antarctic and Polish populations. Pol Polar Res 33:63-80

Committee for Environmental Protection (2011) CEP non-native species manual. Antarctic Treaty Secretariat, Buenos Aires

Convey P (2008) Non-native species in Antarctic terrestrial and freshwater environments: presence, sources, impacts and predictions. In: Rogan-Finnemore $M$ (ed) Non-native species in the Antarctic-proceedings. Gateway Antarctica, Christchurch, pp 97-130

Convey P (2013) Antarctic ecosystems. In: Levin SA (ed) Encyclopedia of biodiversity, vol 1, 2nd edn. Elsevier, San Diego, pp 179-188

Convey P, Lebouvier M (2009) Environmental change and human impacts on terrestrial ecosystems of the sub-Antarctic islands between their discovery and the mid-twentieth century. Pap Proc R Soc Tasmania 143:33-44

Convey P, Quintana RD (1997) The terrestrial arthropod fauna of Cierva Point SSSI, Danco Coast, northern Antarctic Peninsula. Eur J Soil Biol 33:19-29

Convey P, Stevens MI, Hodgson DA, Smellie JL, Hillenbrand C-D, Barnes DKA, Clarke A, Pugh PJA, Linse K, Cary SC (2009) Exploring biological constraints on the glacial history of Antarctica. Quat Sci Rev 28:3035-3048

Convey P, Hughes KA, Tin T (2012) Continental governance and environmental management mechanisms under the Antarctic Treaty System: sufficient for the biodiversity challenges of this century? Biodiversity $13: 1-15$

Corte A (1961) La primera fanerogama adventicia hallada en el continente Antartico. Contribucion del Instituto Antartico Argentino 62:1-14

Council of Managers of Antarctic National Programs (COMNAP) (2008) Survey on existing procedures concerning introduction of non-native species in Antarctica. Information Paper 98. Antarctic Treaty Consultative Meeting XXXI, Kiev, Ukraine, 2-13 June 2008

Council of Managers of National Antarctic Programs (COMNAP) (2013) Use of hydroponics by National Antarctic Programs. Information Paper 31. Antarctic Treaty Consultative Meeting XXXVI, Brussels, Belgium, 20-29 May 2013

Cowan DA, Chown SL, Convey P, Tuffin M, Hughes KA, Pointing S, Vincent WF (2011) Non-indigenous microorganisms in the Antarctic_-assessing the risks. Trends Microbiol 19:540-548

Crawley MJ, Harvey PH, Purvis A (1996) Comparative ecology of the native and alien floras of the British Isles. Philos Trans R Soc B 351:1251-1259. doi:10.1098/rstb.1996.0108

Cuba-Díaz M, Troncoso JM, Cordero C, Finot VL, Rondanelli-Reyes M (2012) Juncus bufonius L., a new alien vascular plant in King George Island, South Shetland Archipelago. Antarct Sci 25:385-386. doi: $10.1017 /$ S0954102012000958

Everatt MJ, Worland MR, Bale JS, Convey P, Hayward SAL (2012) Pre-adapted to the maritime Antarctic?-rapid cold hardening of the midge, Eretmoptera murphyi. J Insect Physiol 58:1104-1111

Frenot Y, Chown SL, Whinam J, Selkirk PM, Convey P, Skotnicki M, Bergstrom DM (2005) Biological invasions in the Antarctic: extent, impacts and implications. Biol Rev 80:45-72

Frenot Y, Convey P, Lebouvier M, Chown SL, Whinam J, Selkirk PM, Skotnicki M, Bergstrom DM (2008) Antarctic and sub-Antarctic biological invasions: sources, extents, impacts and implications. In: Rogan-Finnemore M (ed) Non-native species in the Antarctic-proceedings. Gateway Antarctica, Christchurch, pp 53-96

Greenslade P (1995) Collembola from the Scotia Arc and Antarctic Peninsula including descriptions of two new species and notes on biogeography. Polskie Pismo Entomologiczne 64:305-319

Greenslade P (2002) Assessing the risk of exotic Collembola invading subantarctic islands: prioritizing quarantine management. Pedobiologia 46:338-344

Greenslade P, Convey P (2012) Exotic Collembola on subantarctic islands: pathways, origins and biology. Biol Invasions 14:405-417

Greenslade P, Wise KAJ (1984) Additions to the collembolan fauna of the Antarctic. Trans R Soc S Aust 108:203-205 
Greenslade P, Potapov M, Russell D, Convey P (2012) Global collembola on Deception Island. J Insect Sci 12:111. http://www.insectscience.org/12.111

Grime JP (1977) Evidence for the existence of three primary strategies in plants and its relevance to ecological and evolutionary theory. Am Nat 111:1169-1194

Hack WH (1949) Nota sobre un colémbolo de la Antartida Argentina Achorutes viaticus Tullberg. Notas del Museo de la Plata 14:211-212

Hodgson D, Convey P, Verleyen E, Vyverman W, McInnes S, Sands CS, Fernández-Carazo R, Wilmotte A (2010) Observations on the limnology and biology of the Dufek Massif, Transantarctic Mountains $82^{\circ}$ South. Polar Sci 4:197-214

Hogg ID, Cary SC, Convey P, Newsham K, O’Donnell T, Adams BJ, Aislabie J, Frati FF, Stevens MI, Wall DH (2006) Biotic interactions in Antarctic terrestrial ecosystems: are they a factor? Soil Biol Biochem 38:3035-3040

Hughes KA, Convey P (2010) The protection of Antarctic terrestrial ecosystems from inter- and intracontinental transfer of non-indigenous species by human activities: a review of current systems and practices. Glob Environ Change 20:96-112

Hughes KA, Convey P (2012) Determining the native/non-native status of newly discovered terrestrial and freshwater species in Antarctica-current knowledge, methodology and management action. J Environ Manag 93:52-66

Hughes KA, Convey P (2014) Alien invasions in Antarctica-is anyone liable? Polar Res 33:22103. doi:10. 3402/polar.v33.22103

Hughes KA, Worland MR (2010) Spatial distribution, habitat preference and colonisation status of two alien terrestrial invertebrate species in Antarctica. Antarct Sci 22:221-231

Hughes KA, Walsh S, Convey P, Richards S, Bergstrom DM (2005) Alien fly populations established at two Antarctic research stations. Polar Biol 28:568-570

Hughes KA, Ott S, Bolter M, Convey P (2006) Colonisation processes. In: Bergstrom D, Convey P, Huiskes AHL (eds) Trends in Antarctic terrestrial and limnetic ecosystems. Springer, Dordrecht, pp 35-54

Hughes KA, Convey P, Maslen NR, Smith RIL (2010) Accidental transfer of non-native soil organisms into Antarctica on construction vehicles. Biol Invasions 12:875-891

Hughes KA, Lee JE, Tsujimoto M, Imura S, Bergstrom DM, Ware C, Lebouvier M, Huiskes AHL, Gremmen NJM, Frenot Y, Bridge PD, Chown SL (2011) Food for thought: risks of non-native species transfer to the Antarctic region with fresh produce. Biol Conserv 144:1682-1689

Hughes KA, Worland MR, Thorne M, Convey P (2013) The non-native chironomid Eretmoptera murphyi in Antarctica: erosion of the barriers to invasion. Biol Invasions 15:269-281

Hughes KA, Huiskes AHL, Convey P (2014) Global movement and homogenisation of biota: challenges to the environmental management of Antarctica? In: Tin T, Liggett D, Maher P, Lamers M (eds) The future of Antarctica: human impacts, strategic planning and values for conservation. Springer, Dordrecht, pp 113-137. doi:10.1007/978-94-007-6582-5_5

Hughes KA, Cowan DA, Wilmotte A (2015) Protection of Antarctic microbial communities_- 'out of sight, out of mind'. Front Microbiol 6:151. doi: 10.3389/fmicb.2015.00151

Huiskes AHL, Gremmen NJM, Bergstrom DM, Frenot Y, Hughes KA, Imura S, Kiefer K, Lebouvier M, Lee JE, Tsujimoto M, Ware C, Van de Vijver B, Chown SL (2014) Aliens in Antarctica: assessing transfer of plant propagules by human visitors to reduce invasion risk. Biol Conserv 171:278-284

Japan (1996) A grass (seed plant) found in Syowa Station area, East Antarctica. Information Paper 66. Antarctic Treaty Consultative Meeting XX, Utrecht, The Netherlands, 9 April-10 May 1996

Joyner CC (1999) Governing the frozen commons: the antarctic regime and environmental protection. University of South Carolina Press, Columbia

Kerry K, Riddle M (eds) (2009) Health of Antarctic wildlife: a challenge for science and policy. Springer, London

Lee JE, Chown SL (2009) Quantifying the propagule load associated with the construction of an Antarctic research station. Antarct Sci 21:471-475

Mack RN, Simberloff D, Lonsdale WM, Evans H, Clout M, Bazzaz FA (2000) Biotic invasions: causes, epidemiology, global consequences, and control. Ecol Appl 10:689-710

McGaughran A, Hogg ID, Stevens MI (2008) Patterns of population genetic structure for springtails and mites in southern Victoria Land, Antarctica. Mol Phylogenet Evol 46:606-618

McGaughran A, Torricelli G, Carapelli A, Frati F, Stevens MI, Convey P, Hogg ID (2010) Contrasting phylogeographical patterns for springtails reflect different evolutionary histories between the Antarctic Peninsula and continental Antarctica. J Biogeogr 37:103-119

Molina-Montenegro M, Carrasco-Urra F, Rodrigo C, Convey P, Valladares F, Gianoli E (2012) Occurrence of the non-native annual bluegrass (Роа аппиа) on the Antarctic mainland and its negative effects on native plants. Conserv Biol 26:717-723 
Molina-Montenegro M, Carrasco-Urra F, Acuna-Rodriquez I, Oses R, Torres-Díaz C, Chwedorzewska KJ (2014) Assessing the importance of human activities for the establishment of the invasive Роа аппиа in Antarctica. Polar Res 33:Article no. 21425. 10.3402/polar.v33.21425

SCAR, New Zealand, IUCN (2012) Antarctic conservation for the 21st century: background, progress, and future directions. Information Paper 35. Antarctic Treaty Consultative Meeting XXXV, Hobart, Australia, 11-20 June 2012

Olech M (1996) Human impact on terrestrial ecosystems in west Antarctica. In: Proceedings of NIPR symposium on polar biology, vol 9, pp 299-306

Olech M (1998) Synantropization of the flora of Antarctica: an issue. In: Faliński JB, Adamowski W, Jackowiak B (eds) Synantropization of plant cover in new Polish research. Phytocoenosis 10, Supplementum Cartographiae Geobotanicae, vol 9, pp 269-273

Olech M (2003) Expansion of alien vascular plant Poа апnиа L. in the vicinity of the Henryk Arctowski Station-a consequence of climate change? In: Olech M (ed) The functioning of polar ecosystems as viewed against global environmental changes. XXIX International Polar Symposium, pp 89-90

Olech M, Chwedorzewska KJ (2011) The first appearance and establishment of an alien vascular plant in natural habitats on the forefield of a retreating glacier in Antarctica. Antarct Sci 23:153-154

Perrings C, Williamson M, Dalmazzone S (2000) The economics of biological invasion. Edward Elgar Publisher, Cheltenham

Pertierra LR, Lara F, Benayas J, Hughes KA (2013) Poa pratensis L., current status of the longestestablished non-native vascular plant in the Antarctic. Polar Biol 36:1473-1481

Peter H-U, Buesser C, Mustafa O, Pfeiffer S (2008) Risk assessment for the Fildes Peninsula and Ardley Island, and development of management plans for their designation as Specially Protected or Specially Managed Areas. German Federal Environment Agency, Dessau

Peter H-U, Braun C, Janowski S, Nordt A, Nordt A, Stelter M (2013) The current environmental situation and proposals for the management of the Fildes Peninsula Region. German Federal Environment Agency, Dessau

Pimentel D, Zuniga R, Morrison D (2005) Update on the environmental and economic costs associated with alien-invasive species in the United States. Ecol Econ 52:273-288

Pugh PJA, Convey P (2008) Surviving out in the cold: Antarctic endemic invertebrates and their refugia. J Biogeogr 35:2176-2186

Rout TM, Moore JL, Possingham HP, McCarthy MA (2011) Allocating biosecurity resources between preventing, detecting, and eradicating island invasions. Ecol Econ 71:54-62

Russell DJ, Hohberg K, Otte V, Christian A, Potapov M, Brückner A, McInnes SJ (2013) The impact of human activities on soil organisms of the maritime Antarctic and the introduction of non-native species in Antarctica. Federal Environment Agency (Umweltbundesamt). http://www.uba.de/uba-info-mediene/4416.html. Accessed 14 Nov 2014

Russell DJ, Hohberg K, Potapov M, Brückner A, Otte V, Christian A (2014) Native terrestrial invertebrate fauna from the northern Antarctic Peninsula: new records, state of current knowledge and ecological preferences-summary of a German federal study. Soil Organ 86:1-58

Russia (1999) Initial environmental evaluation: compacted snow runway at the Larsemann Hills. Information Paper 79. Antarctic Treaty Consultative Meeting XXIII, Lima, Peru, 24 May-4 Jun 1999

Shaw JD (2013) Southern Ocean Islands invaded: conserving biodiversity in the world's last wilderness. In: Foxcrof LC, Pysek P, Richardson DM, Genovesi P (eds) Plant invasions in protected areas: patterns, problems and challenges. Springer, Dordrecht, pp 449-470

Simberloff D (2002) Today Tiritigi Matangi, tomorrow the world! Are we aiming to low in invasives control? In: Veitch CR, Clout MN (eds) Turning the tide: the eradication of invasive species. Proceedings of the international conference on eradication of island invasives. IUCN SSC Invasive Species Specialist Group. IUCN, Gland, pp 4-9

Simberloff D (2003) How much information on population biology is needed to manage introduced species? Conserv Biol 17:83-92

Smith RIL (1984) Terrestrial plant biology of the sub-Antarctic and Antarctic. In: Laws RM (ed) Antarctic ecology, vol 1. Academic Press, London, pp 61-162

Smith RIL (1996) Introduced plants in Antarctica: potential impacts and conservations issues. Biol Conserv 76:135-146

Smith RIL (2003) The enigma of Colobanthus quitensis and Deschampsia antarctica in Antarctica. In: Huiskes AHL, Gieskes WWC, Rozema J, Schorno RMC, Van der Vies SM, Wolff WS (eds) Antarctic biology in a global context. Proceedings of the VIII SCAR International Biology Symposium. Backhuys Publishing, Leiden, pp 234-239

Smith J (2005) Shoo fly! http://www.aad.gov.au/default.asp?casid=19699. Accessed 23 Nov 2014 
Smith RIL (2011) Alien introductions-why are the Treaty Parties and COMNAP sitting on their hands? Antarct Sci 23:105

Smith RIL, Richardson M (2011) Fuegian plants in Antarctica: natural or anthropogenically assisted immigrants. Biol Invasions 13:1-5

Terauds A, Chown SL, Morgan F, Peat HJ, Watts DJ, Keys H, Convey P, Bergstrom DM (2012) Conservation biogeography of the Antarctic. Divers Distrib 18:726-741

Thompson K, Hodgson JG, Rich TCG (1995) Native and alien invasive plants: more of the same? Ecography $18: 390-402$

Tilbrook PJ (1967) Terrestrial invertebrate fauna of maritime Antartica. Philos Trans R Soc B 252:261-278

Tin T, Fleming ZL, Hughes KA, Ainley DG, Convey P, Moreno CA, Pfeiffer S, Scott J, Snape I (2009) Impacts of local human activities on the Antarctic environment. Antarct Sci 21:3-33

Tsujimoto M, Imura S (2012) Does a new transportation system increase the risk of importing non-native species to Antarctica? Antarct Sci 24:441-449

Tsujimoto M, Imura S, Kanda H (2010) Molecular systematics of a non-native vascular plant found near the Syowa Station, Antarctica. In: Poster at the International Polar Year Oslo science conference, Oslo, Norway, Unpublished

United Kingdom, Spain (2010) Eradication of a vascular plant species recently introduced to Whaler's Bay, Deception Island. Information Paper 43. Antarctic Treaty Consultative Meeting XXXIII, Punta del Este, Uruguay, 3-14 May 2010

Volonterio O, de León RP, Convey P, Krzeminska E (2013) First record of Trichoceridae (Diptera) in the maritime Antarctic. Polar Biol 36:1125-1131

Whinam J, Chilcott N, Bergstrom DM (2005) Subantarctic hitchhikers: expeditioners as vectors for the introduction of alien organisms. Biol Conserv 121:207-219

Wise KAJ (1971) The Collembola of Antarctica. Pac Insects Monogr 25:57-74

Wódkiewicz M, Galera H, Chwedorzewska KJ, Gielwanowska I, Olech M (2013) Diaspores of the introduced species Pоа аппиа L. in soil samples from King George Island (South Shetlands, Antarctica). Arct Antarct Alp Res 45:415-419 